\title{
ĐÁNH GIÁ KẾT QUẢ PHẪU THUẬT CẤT THÙY PHỔI QUA NộI SOI LỒNG NGỰC TRONG ĐIỀU TR!̣ UNG THU’ PHỔI
}

Trần Minh Bảo Luân*, Nguyến Hoài Nam*

\section{TÓM TẮT}

52 trường hợp phẫu thuật cắt thùy phổi qua nội soi lồng ngực được thực hiện tại BV Đại học Y Dược TPHCM từ 01/2011 đến 01/2016, trong đó 18 trường hợp thùy trên phổi trái, 15 trường hợp thùy dưới phổi trái, 10 trường hợp thùy trên phổi phải, 8 trường hợp thùy dưới phổi phải và 1 trường hợp thùy giữa. Kích thước khối u trung bình $4,2 \pm 0,5(2,5-5 \mathrm{~cm})$, nằm ngoại vi và không xâm lấn các mạch máu vùng rốn phổi. Có 32 trường hợp kèm hạch: trung thất (14 trường hợp), rốn phổi (18 trường hợp). 4 trường hợp giai đoạn $\mathrm{IA}, 26$ trường hợp giai đoạn $\mathrm{IB}, 16$ trường hợp IIA, 6 trường hợp IIIA. Thời gian phẫu thuật trung bình $105 \pm 38,5$ (65 - $185 \mathrm{ph})$; Lượng máu mất: $150 \pm 20(100-180 \mathrm{ml})$; Thời gian DLMP: $2,05 \pm 0,5$ ( 1 - 3 ngày); Thời gian nằm viện sau mố: $4,5 \pm 1,5$ ( $4-7$ ngày). Tai biến và biến chứng: 1 trường hợp chuyển sang mổ mở vì khó khăn về mặt kỹ thuật, 1 trường hợp xì khí kéo dài đòi hỏi nội soi lồng ngực lại và 1 trường hợp tràn khí - dịch màng phổi sau phẫu thuật 3 tuần và chỉ cần điều trị bằng chọc hút khí - dịch màng phổi. Không trường hợp nào rách ĐM hay $\mathrm{TM}$ phổi gây chảy máu lượng lớn đòi hỏi phải mở ngực khẩn cấp, không ghi nhận các tai biến và biến chứng khác như: chảy máu sau mổ, viêm phổi, xẹp phổi, nhiểm trùng vết mổ... Thuốc giảm đau sau mổ: tất cả 52 trường hợp của chúng tôi chỉ cần dùng NSAID dạng chích kèm Paracetamol truyền tĩnh mạch trong 2 ngày đầu sau mổ và chuyển sang Acetaminophen uống trong 3 ngày tiếp theo. Phẫu thuật nội soi lồng ngực cắt thùy phổi cho thấy nhiều ưu điểm: vết mổ nhỏ, thẫm mỹ cao, không banh kéo xương sườn nên ít đau sau mổ, thời gian phục hồi và nằm viện ngắn...
Hiện nay, kỹ thuật này đang được áp dụng rộng rãi và tính khả thi về mặt kỹ thuật, hiệu quả trong điều trị ung thư cũng đã được nhiều tác giả cố gắng chứng minh qua nhiều nghiên cứu.

\section{SUMMARY}

THE RESULTS OF VATS LOBECTOMY IN TREATMENT OF EARLY STAGE LUNG CANCER

52 cases of VATS lobectomy were performed at University Medical Center of Ho Chi Minh city from 01/2011 to 09/2016, including 18 cases of left upper lobe, 10 cases of left lower lobe, 15 cases of right upper lobe, 8 cases of right lower lobe and 1 case of middle lobe. The average tumor size 4,2 \pm 0.5 (2.5 - 5 $\mathrm{cm})$, are located at peripheral lung tissue and noninvasive pulmonary blood vessels. There are 32 cases with lymph nodes: mediastinum lympho nodes (14 cases), lung hilum lympho nodes (18 cases). 4 cases of lung cancer stage IA, 26 cases of stage IB, 16 cases of stage IIA and 6 cases of IIIA. The mean durations of operative time $105 \pm$ 38.5 (65-185 min), intraoperative blood loss: 150 $\pm 20(100-180 \mathrm{ml})$, the mean durations of chest drainage: $2.05 \pm 0.5$ (1-3 days); the mean postoperative hospitalization: $4.5 \pm 1.5$ (4-7 days). Complications: a case switch to open surgery because of technical difficulties, one case of long airleak needed to redo VATS and a case of pneumothorax - pleural effusion happened at 3 weeks after surgery and just treated with simply aspiration. No case of massive bleeding due to

* Bộ môn phẫu thuật Lồng Ngục - Tim Mạch, Đại học Y Duợc TPHCM

Người chịu trách nhiệm khoa họ: PGS.TS. Nguyễn Hoài Nam Ngày nhận bài: 01/05/2018 - Ngày Cho Phép Đăng: 20/05/2018

Phản Biện Khoa học: PGS.TS. Đặng Ngoc Hùng GS.TS. Lê Ngoc Thành 
laceration of pulmonary artery or pulmonary vein requiring emergency thoracotomy, no other complications such as postoperative bleeding, pneumonia, atelectasis, wound infection ... Postoperative analgesics: only injectable NSAID combine Paracetamol I.V was used within 2 days after surgery and switched to acetaminophen in the next 3 days in all of our cases.

VATS lobectomy was proved as a procedure with many advantages such as small incisions, highly cosmetic, less postoperative pain due to no rib retractor, shorter recovery time and hospital stay.... Curently, VATS lobectomy technique is widely applied and technically feasibilities, effective in treatment of lung cancer have also been proved by many authors through many studies.

Từ khóa: VATS lobectomy, Cắt thùy phổi qua nội soi lồng ngực.

\section{I. ĐẠTT VẤN ĐỀ}

Ung thư phổi là bệnh lý rất thường gặp trong dân số, chiếm tỷ lệ cao nhất trong các loại ung thư tại Việt Nam. Trước đây, phẫu thuật điều trị ung thư phổi được thực hiện bằng phẫu thuật mở ngực kinh điển, với vết mổ dài hơn $15 \mathrm{~cm}$ và banh các xương sườn để vào lồng ngực và các thùy phổi bị ung thư. Với vết mổ dài và thao tác banh xương sườn nên bệnh nhân rất đau sau phẫu thuật, thậm chí nhiều trường hợp đau dai dẳng kéo dài dù đã được phẫu thuật trước đó nhiều tháng. Ngày nay, với sự tiến bộ của khoa học kỹ thuật, sự ra đời của hệ thống thấu kính, camera nội soi và các dụng cụ phẫu thuật, thiết bị cắt và khâu phổi tự động đã tạo ra kỹ nguyên mới trong phẫu thuật.

Nội soi lồng ngực được thực hiện đầu tiên bởi Jacobaeus năm 1910 bằng ống soi cứng tại bệnh viện Serafimerla sarettet ở Stockholm. Năm 1925, ông báo cáo 120 trường hợp nội soi lồng ngực thành công, trong đó gồm tách dính xoang màng phổi nhằm điều trị lao phổi và chẩn đoán $\mathrm{u}$ màng phổi. Từ thời điểm Jacobaeus báo cáo cho đến thập niên 50 , có rất nhiều báo cáo khác về nội soi lồng ngực với số lượng lớn bệnh nhân đã được thực hiện ở các nước Âu - Mỹ ${ }^{(2)}$.

Năm 1989, phẫu thuật nội soi cắt túi mật lần đầu tiên thực hiện thành công. Từ đó, phẫu thuật nội soi ổ bụng phát triển mạnh mẽ và lan rộng khắp thế giới. Điều này đã thúc đẩy các phẫu thuật viên ứng dụng phẫu thuật nội soi trong điều trị bệnh lý lồng ngực thành công như: cắt phổi không điển hình bằng stapler trong điều trị nốt đơn độc phổi, cắt kén khí qua nội soi lồng ngực trong tràn khí màng phổi tự phát... Đến năm 1992, cắt thùy phổi bằng phẫu thuật nội soi lồng ngực lần đầu tiên được thực hiện thành công ${ }^{(6)}$. Ngày nay, nhiều trung tâm trên thế giới đã áp dụng kỹ thuật này. Tuy nhiên, về mặt kỹ thuật thì cũng còn chưa được thống nhất và các chỉ định áp dụng cũng là vấn đề được bàn cải nhiều trong phẫu thuật cắt thùy phổi điều trị ung thư phổi. Trên cơ sở đó, chúng tôi thực hiện nghiên cứu nhằm đánh giá kết quả của phẫu thuật nội soi lồng ngực cắt thùy phổi trong điều trị ung thư phổi.

\section{II. ĐỐI TƯợNG VÀ PHƯƠNG PHÁP NGHIÊN CỨU}

2.1. Phương pháp nghiên cứu: Tiền cứu mô tả, không nhóm chứng.

2.2. Đối tượng nghiên cứu: tất cả bệnh nhân ung thư phổi có chỉ định và được phẫu thuật cắt thùy phổi qua NSLN tại BV ĐHYD TPHCM từ $01 / 2011$ đến $01 / 2016$.

\subsubsection{Chỉ định áp dụng cắt thùy phổi qua NSLN:}

Ung thư phổi giai đoạn $\mathrm{I}$ và $\mathrm{II}^{(1)}$; kích thước u nhỏ hơn $5 \mathrm{~cm}(4-6 \mathrm{~cm})$ nằm ở ngoại biên ${ }^{(6,9,10)}$, không xâm lấn mạch máu, thành ngực, rảnh liên thùy, cơ hoành và màng ngoài $\operatorname{tim}^{(6,10)}$; bệnh nhân không xạ trị vùng ngực trước đó; chức năng 
hô hấp đảm bảo thông khí một phổi tốt trong quá trình gây mê phẫu thuật.

\subsubsection{Kỹ thuật cắt thùy phổi qua NSLN:}

Hiện nay có nhiều kỹ thuật được mô tả, nhưng khác nhau chủ yếu về vị trí và số trocar: từ 1 vết mổ nhỏ và 1 lổ trocar cho đến 1 vết mổ nhỏ và 3 lổ trocar. Mặc dù, cắt thùy phổi qua nội soi có thể thực hiện được chỉ với 1 vết mổ nhỏ để thao tác và

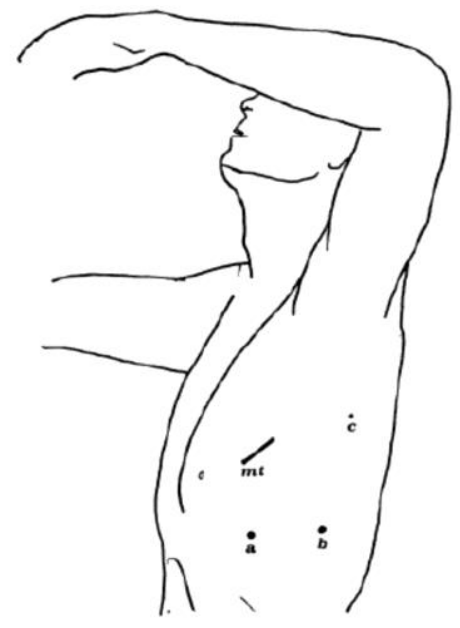

Tu thế bệnh nhân và vị tri trocar, vết mổ nhỏ để thao tác

Bệnh nhân tư thế nằm nghiêng $90^{\circ}$, gối dưới nách và bàn mổ được gập lại vùng hông lưng để hạ thấp xương vùng chậu xuống dưới, nhờ đó khoang liên sườn dãn ra tối đa và không hạn chế camera hay dụng cụ thao tác khi xoay chuyển. Camera $30^{\circ}$ được dùng để quan sát toàn bộ khoang màng phổi qua trocar LS 8 hoặc 9 và đánh giá lại vị trí khối u cũng như các thương tổn kèm theo để quyết định tiến hành cắt thùy phổi. Dùng Ring forceps hoặc Grasper nội soi để vén phổi qua lổ trocar còn lại. Có thể dùng dụng cụ nội soi hoặc dụng cụ phẫu thuật mở kinh điển để bóc tách các cấu trúc rốn phổi dưới màn hình nội soi qua vết mổ $5 \mathrm{~cm}$. Các nhánh động mạch và tĩnh mạch phổi được cắt bằng stapler 2,0 hoặc $2,5 \mathrm{~mm}$, và phế quản hoặc nhu mô phổi được cắt bằng stapler 3,5 hoặc $4,5 \mathrm{~mm}$. Khi tiến hành phẫu

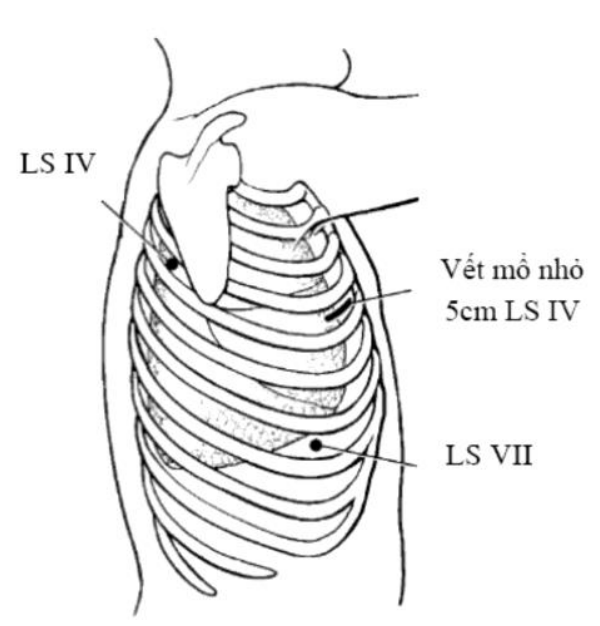

1 lổ trocar cho camera, kỹ thuật này không được áp dụng rộng rãi vì thao tác khó khăn và thời gian phẫu thuật kéo dài. Vì vậy, chúng tôi thường áp dụng kỹ thuật: 1 vết mổ khoảng $1 \mathrm{~cm}$ LS 8 đường nách trước và vết mổ khoảng $1 \mathrm{~cm}$ LS 9 đường nách sau cho camera hoặc dùng cụ để vén phổi; vết mổ khoảng 3-4cm LS 4 hoặc 5 đường nách giữa để thao tác và phẫu tích rốn phổi.

thuật cắt thùy phổi qua nội soi lồng ngực thì có một số điểm khác với phẫu thuật mở kinh điển như: bộc lộ rốn phổi đòi hỏi cả hai mặt trước và sau khác với mổ mở thường là bóc tách từ rãnh gian thùy; các mạch máu và phế quản được cắt theo trình tự không như mổ mở kinh điển là: tĩnh mạch hay động mạch trước rồi mới cắt phế quản sau cùng.

\subsubsection{Thu thập số liệu và đánh giá kết quả:}

Số liệu được thu thập từ bệnh án mẫu với các yếu tố được ghi nhận: triệu chứng lâm sàng, Xquang ngực thẳng và nghiêng, $\mathrm{CT}$ scan ngực cản quang, nội soi phế quản, tế bào học trước $\mathrm{PT}$ (qua NSPQ hay FNA xuyên thành ngực), PET Scan (nếu có); Giai đoạn ung thư phổi trước và sau $\mathrm{PT}$, thời gian $\mathrm{PT}$, các tai biến và biến chứng trong và sau mổ... Bệnh nhân được tái khám 1 
tuần, mỗi tháng sau PT trong năm đầu và mỗi 3 tháng trong năm tiếp theo.

\subsection{4. Đánh giá kết quả}

- Kết quả tốt: thực hiện thành công phẫu thuật, không tai biến hay biến chứng.

- Kết quả trung bình: thực hiện thành công phẫu thuật với các tai biến nhỏ được xử trí tốt bằng nội soi. Các biến chứng sau mổ nhưng không phải mổ lại.

- Kết quả xấu: Không thực hiện được phẫu thuật noi soi, phải chuyển mở ngực. Các biến chứng sau mổ như: chảy máu, xẹp phổi, mủ màng phổi ... phải mổ lại xử trí thương tổn.

- Tử vong trong hay sau mổ.

\section{KẾT QUẢ NGHIÊN CÚU}

Trong thời gian từ $01 / 2011$ đến $01 / 2016$, tại BV Đại học Y Dược TPHCM chúng tôi đã thực hiện được 52 trường hợp phẫu thuật cắt thùy phổi và nạo hạch qua nội soi lồng ngực điều trị ung thư phổi nguyên phát.

Tuổi: trung bình $62 \pm 9,3(46-75)$

Giới: tỷ lệ nam/ nữ: $\quad 2 / 1$

\section{Triệu chứng lâm sàng:}

Không triệu chứng: $\quad 25$ trường hợp (phát hiện tình cờ).

Đau ngực: $\quad 18$ trường hợp.

Ho kéo dài: $\quad 5$ trường hợp.

Ho ra máu: $\quad 4$ trường hợp.

\section{CT scan ngực cản quang:}

\section{Vị trí u:}

U thùy trên phổi $(\mathrm{T}): \quad 18$ trường hợp.

$\mathrm{U}$ thùy dưới phổi $(\mathrm{T}): 15$ trường hợp.

$\mathrm{U}$ thùy trên phổi $(\mathrm{P})$ : 10 trường hợp.

$\mathrm{U}$ thùy dưới phổi $(\mathrm{P}): 8$ trường hợp.

$\mathrm{U}$ thùy giữa phổi $(\mathrm{P})$ : 1 trường hợp.

52 trường hợp đều nằm ngoại vi, không xâm lấn các mạch máu rốn phổi.
Kích thước u: 4,2 \pm 0,5 ( 2,5-5cm).

\section{Hạch:}

Không: 20 trường hợp.

Trung thất: 14 trường hợp.

Rốn phổi: 18 trường hợp.

Giai đoạn ung thư phổi sau phẫu thuật:

IA: $\quad 4$ trường hợp.

IB: $\quad 26$ trường hợp.

IIA: $\quad 16$ trường hợp.

IIIA: $\quad 6$ trường hợp.

Nội soi phế quản: xác định tế bào học 18 trường hợp trước phẫu thuật.

\section{Phẫu thuật:}

Thời gian phẫu thuật: $105 \pm 38,5$ (65-185 phút)

Lượng máu mất: $150 \pm 20(100-180 \mathrm{ml})$

Thời gian DLMP: 2,05 $\pm 0,5$ ( 1 - 3 ngày)

Thời gian nằm viện sau mổ: 4,5 = 1,5 (4-7 ngày)

Tai biến và biến chứng:

1 trường hợp chuyển mổ mở vì hạch dính chặt nhánh $\mathrm{S} 1,2$ trong cắt thùy trên phổi $(\mathrm{T})$.

1 trường hợp tràn khí-dịch MP sau mổ 3 tuần, chỉ cần điều trị bằng chọc hút đơn thuần.

1 trường hợp tràn khí màng phổi do xì khí từ nhu mô phồi vùng rãnh liên thùy đòi hỏi phải nội soi lồng ngực khâu chổ xì khí.

Không trường hợp nào chảy máu do rách ĐM, TM phổi.

Không trường hợp chảy máu sau mổ.

Các biến chứng khác: không ghi nhận trường hợp nào.

Thuốc giảm đau: tất cả bệnh nhân đều được dùng NSAID dạng chích phối hợp Paracetamol truyền tĩnh mạch trong 2 ngày sau mổ, sau đó chuyển sang dạng uống với Paracetamol trong 3 ngày tiếp theo. 


\section{Tái phát và di căn $x a:$}

Tất cả bệnh nhân đều được hóa trị hỗ trợ sau phẫu thuật $4-6$ chu kỳ với phác đồ Paclitaxel + Carboplatin weekly và thời gian theo dõi trung bình: $36 \pm 6,5$ tháng (2 -53 tháng):

- 3 trường hợp di căn xa và tử vong sau 36 tháng theo dõi: 2 trường hợp giai đoạn IIIA và 1 trường hợp giai đoạn IIA.

- 1 trường hợp giai đoạn IIA tái phát và di căn xa sau 32 tháng theo dõi, vẫn đang được tiếp tục hóa trị hỗ trợ.

\section{Kết quả sớm PTNSLN:}

Tốt: $\quad 94,3 \%$

Trung bình: $1,9 \%$

Xấu: $\quad 3,8 \%$

\section{BÀN LUẬN}

Trong nghiên cứu của chúng tôi, 52 trường hợp phẫu thuật cắt thùy phổi qua nội soi lồng ngực, trong đó 18 trường hợp cắt thùy trên phổi trái, 15 trường hợp thùy dưới phổi trái, 10 trường hợp thùy trên phổi phải, 8 trường hợp thùy dưới phổi phải, 1 trường hợp thùy giữa. Kích thước khối u trung bình $4,2 \pm 0,5(2,5-5 \mathrm{~cm})$, nằm ngoại vi và không xâm lấn các mạch máu vùng rốn phổi. Có 32 trường hợp kèm hạch: trung thất (14 trường hợp), rốn phổi (18 trường hợp). 4 trường hợp ung thư phổi giai đoạn IA, 26 trường hợp giai đoạn IB, 16 trường hợp giai đoạn IIA, 6 trường hợp giai đoạn IIIA. Thời gian phẫu thuật trung bình $105 \pm 38,5$ (65 - 185 phút); Lượng máu mất: $150 \pm 20(100-180 \mathrm{ml})$; Thời gian DLMP: 2,05 \pm 0,5 ( 1 - 3 ngày); Thời gian nằm viện sau mổ: 4,5 $\pm 1,5$ ( 4 - 7 ngày).

So với các tác giả khác: Lewis ${ }^{(8)}$ thực hiện 250 trường hợp với thời gian phẫu thuật trung bình 78,8ph, lượng máu mất trong mổ trung bình $100 \mathrm{ml}$, thời gian nằm viện sau mổ trung bình 2,3 ngày; tác giả Kirby ${ }^{(3)}$ thực hiện 25 trường hợp với thời gian phẫu thuật trung bình là $161 \mathrm{ph}$, lượng máu mất trong mổ trung bình $250 \mathrm{ml}$, thời gian nằm viện sau mổ trung bình 7,1 ngày; tác giả Walker $^{(15)}$ thực hiện 159 trường hợp với thời gian phẫu thuật trung bình 130ph. Nghiên cứu của chúng tôi về lượng máu mất trong mổ và thời gian nằm viện sau phẫu thuật cũng tương đương với các tác giả trên; về thời gian phẫu thuật của chúng tôi dài hơn so với các tác giả khác. Tuy nhiên, đây là bước đầu chúng tôi áp dụng phẫu thuật nội soi để cắt thùy phổi nên những trường hợp đầu tiên thực hiện phẫu thuật rất lâu, và thời gian phẫu thuật được rút ngắn dần cho những trường hợp tiếp theo. Do vậy, thời gian phẫu thuật phụ thuộc rất nhiều vào đường cong huấn luyện. Chúng tôi tin rằng với số lượng bệnh nhân lớn hơn trong các báo cáo tiếp theo của chúng tôi, thời gian phẫu thuật sẽ rút ngắn hơn đáng kể.

Về tai biến và biến chứng, nghiên cứu của chúng tôi có 1 trường hợp chuyển sang mổ mở vì khó khăn về mặt kỹ thuật, 1 trường hợp tràn khí màng phổi do xì khí từ nhu mô phồi vùng rãnh liên thùy đòi hỏi phải nội soi lồng ngực khâu chổ xì khí và 1 trường hợp tràn khí - dịch màng phổi sau phẫu thuật 3 tuần và chỉ cần điều trị bằng chọc hút khí - dịch màng phổi. Không trường hợp nào rách ĐM hay $\mathrm{TM}$ phổi gây chảy máu lượng lớn đòi hỏi phải mở ngực khẩn cấp, không ghi nhận các tai biến và biến chứng khác như: chảy máu sau mổ, viêm phổi, xẹp phổi, nhiểm trùng vết mổ... Tác giả Jesus Loscertales ${ }^{(6)}$ từ năm 1993 đến 2007 thực hiện 260 trường hợp cắt thùy phổi nội soi trong đó: 76 trường hợp thùy trên phổi phải, 49 trường hợp thùy trên phổi trái, 42 trường hợp thùy dưới phổi trái, 41 trường hợp thùy dưới phổi phải, 11 trường hợp thùy giữa, 8 trường hợp cắt 2 thùy giữa và dưới, 9 trường hợp cắt thùy giữa và trên. Thời gian phẫu thuật trung bình 95 phút, chuyển mổ hở 9,2\% (24 trường hợp) trong đó 12 trường hợp chảy máu, 11 trường hợp khó khăn về mặt kỹ thuật. Thời gian nằm viện trung bình sau phẫu thuật là 4,1 ngày. Từ 1994 đến 2002, tác giả Akinori Iwasaki ${ }^{(1)}$ thực hiện phẫu thuật 100 trường hợp cắt thùy phổi qua 
nội soi lồng ngực, không biến chứng hay tử vong chu phẫu, có 3 trường hợp chuyển mổ hở trong đó: 1 trường hợp chảy máu không kiểm soát được qua nội soi, 2 trường hợp khó khăn về mặt kỹ thuật. Daniel ${ }^{(4)}$ và cộng sự báo cáo 110 trường hợp cắt thùy phổi nội soi, tỷ lệ chuyển mổ mở là $1,8 \%$; tử vong chu phẫu là $3,6 \%$, không tai biến trong mổ. Nghiên cứu của chúng tôi với số liệu còn nhỏ nên các biến chứng được ghi nhận không đáng kể khi so sánh với các tác giả khác, điều này có thể do bước đầu áp dụng phẫu thuật nội soi cắt thùy phổi nên chúng tôi chọn lựa bệnh nhân với khối u phổi gọn gàng, nằm ngoại vi và không hình ảnh xâm lấn mạch máu lớn vùng rốn phổi; không có bệnh lý nội khoa kèm theo, nên phẫu thuật được thực hiện dể hơn và ít biến chứng hơn. Tuy nhiên, thời gian gần đây chúng tôi cũng dần dần mở rộng chỉ định cho một số trường hợp giai đoạn IIIA.

Trong nghiên cứu của chúng tôi, có 32 trường hợp kèm hạch trung thất và rốn phổi đều được chúng tôi nạo hạch triệt để bằng phẫu thuật nội soi; về mặt kỹ thuật đa số các tác giả đều cho rằng phẫu thuật được thực hiện bởi phẫu thuật viên có kỹ năng thì việc cắt thùy phổi bao gồm cả nạo hạch như phẫu thuật mở tiêu chuẩn. Tác giả Shigemura $^{(11)}$ chứng minh hiệu quả của việc nạo hạch trung thất qua nội soi cũng như các báo cáo trước đây cũng khẳng định điều này ${ }^{(4,13)}$. Tác giả Shiraishi ${ }^{(12)}$ cũng cho rằng về mặt kỹ thuật, phẫu thuật nội soi cắt thùy phổi và nạo hạch tương đương như phẫu thuật mở tiêu chuẩn. Tác giả Sugi ${ }^{(13)}$ và cộng sự cũng cho thấy không có sự khác nhau về tỷ lệ sống còn khi so sánh với phẫu thuật mở trước đây: 90\% so với 93\% sau 3 năm và $90 \%$ so với $85 \%$ sau 5 năm. Các biến chứng sau phẫu thuật cũng không có sự khác biệt giữa hai nhóm phậu thuật nội soi và phẫu thuật mở ngực kinh điển ngoại trừ báo cáo của Kirby có một vài trường hợp xì khí hơn 4 ngày ${ }^{(7)}$. Về kết quả trung hạn của phẫu thuật nội soi lồng ngực cắt thùy phổi và nạo hạch, tỷ lệ sống còn sau 36 tháng theo dõi là $94,2 \%$, tái phát và di căn xa
$7,6 \%$. So với các tác giả khác tỷ lệ sống còn sau 3 năm trong nghiên cứu của Lewis ${ }^{(8)}$ là $92 \%$, Sugi $^{(13)}$ là $90 \%$; nghiên cứu của chúng tôi cũng tương đương như của các tác giả nói trên và tỷ lệ này cũng tương đương so với mổ mở kinh điển. Vì vậy, có thể cho rằng phẫu thuật nội soi lồng ngực có thể thay thế phẫu thuật mở kinh điển trong các trường hợp ung thư phổi giai đoạn sớm.

Tất cả 52 trường hợp của chúng tôi chỉ cần dùng NSAID dạng chích kèm paracetamol truyền tĩnh mạch trong 2 ngày đầu sau mổ và chuyển sang paracetamol uống trong 3 ngày tiếp theo; Nhiều báo cáo cho thấy phẫu thuật nội soi với nhiều ưu điểm như tính thẫm mỹ cao với vết mổ nhỏ, không banh kéo xương sườn nên ít đau sau phẫu thuật, thời gian phục hồi ngắn, rút ngắn thời gian nằm viện: báo cáo của tác giả Sugiura cho thấy thời gian cần sử dụng giảm đau ngoài màng cứng cho bệnh nhân rất ngắn so với phẫu thuật mơ (14); trong khi Demmy và Curtis cho rằng đau sau phẫu thuật ít hơn và thời gian hồi phục của bệnh nhân ngắn hơn đặc biệt với những bệnh nhân nguy cơ cao ${ }^{(5)}$. So với mổ mở kinh điển tất cả bệnh nhân đều được giảm đau ngoài màng cứng kết hợp với thuốc giàm đau dạng chích khác trong 3 ngày đầu sau mổ. Điều này cho thấy mức độ đau sau mổ của phẫu thuật noi soi giảm rất nhiều; Vì phẫu thuật nội soi lồng ngực không banh kéo, mở rộng khoang liên sườn như trong mổ mở là nguyên nhân của đau sau phẫu thuật nên phẫu thuật nội soi ít đau sau mổ rất nhiều so với mổ mở.

\section{KẾT LUẬN}

Phẫu thuật nội soi lồng ngực cắt thùy phổi cho thấy nhiều ưu điểm: vết mổ nhỏ, thẫm mỹ cao, không banh kéo xương sườn nên ít đau sau mổ, thời gian phục hồi và nằm viện ngắn... Hiện nay, kỹ thuật này đang được áp dụng rộng rãi và tính khả thi về mặt kỹ thuật, hiệu quả trong điều trị ung thư cũng đã được nhiều tác giả cố gắng chứng minh qua nhiều nghiên cứu. Nghiên cứu bước đầu của chúng tôi tuy số liệu còn ít, nhưng cũng góp phần chứng minh những ưu điểm này. 


\section{TÀI LIỆ THAM KHẢO}

1. Akinori Iwasaki. Results of videoassisted thoracic surgery for stage I/II non-small cell lung cancer. European Journal of Cardiothoracic Surgery 26 (2004) 158-164.

2. Chad j. Davis and Charles j. Filipi: "A history of Endoscopy Surgery". Princles of Laparoscopic Surgery. Springer Verlag. 1997: 3-20.

3. Craig SR, Leaver HA, Yap PL et al. Acute phase responses following minimal access and conventional thoracic surgery. Eur J Cardiothorac Surg 2001;20:455- 463.

\section{Daniels LJ, Balderson SS,} OnaitisMWet al. Thoracoscopic lobectomy: A safe and effective strategy for patients with stage I lung cancer. Ann Thorac Surg 2002;74:860-864.

5. Demmy TL, Curtis JJ. Minimally invasive lobectomy directed toward frail and high-risk patients: A case-control study. Ann Thorac Surg 1999; 68:194 -200.

6. Jesus Loscertales et al. VideoAssisted Surgery for Lung Cancer. State of the Art and Personal Experience. Asian Cardiovasc Thorac Ann 2009; 17:313-26.

7. Kirby TJ, Mack MJ, Landreneau RJ et al. Lobectomy-video-assisted thoracic surgery versus muscle-sparing thoracotomy. A randomized trial. J Thorac Cardiovasc Surg 1995;109:997-1002.

8. Lewis RJ, Caccavale RJ. Videoassisted thoracic surgical non-rib spreading simultaneously stapled lobectomy (VATS(n)SSL). Semin Thorac Cardiovasc Surg 1998;10:332-339.

9. McKenna RJ Jr.VATS Lobectomy with mediastinal lymph node sampling or dissection. Technique of Pulmonary Resection . Chest Surgery Clinis of North Amercan. W.B Saunders Company. Vol 5. No.2. 1995: 223.232.

10. Piergiorgio Solli, Indications and Developments of Video-Assisted Thoracic Surgery in the Treatment of Lung Cancer. The Oncologist 2007;12:1205-1214.

\section{Shigemura N, Akashi A, Funaki S et}

al. Long-term outcomes after a variety of videoassisted thoracoscopic lobectomy approaches for clinical stage IA lung cancer: A multiinstitutional study. J Thorac Cardiovasc Surg 2006;132:507-512.

12. Shiraishi $\mathbf{T}$ et al. A Completely Thoracoscopic Lobectomy Segmentectomy for Primary Lung Cancer - Technique Feasibility and Advantages. Thorac Cardiov Surg 2006; 54: 202-207.

\section{Sugi K, Sudoh M, Hirazawa $K$ et al.} Intrathoracic bleeding during videoassisted thoracoscopic lobectomy and segmentectomy. Kyobu Geka 2003;56:928 -931. In Japanese. 20

14. Sugiura H, Morikawa T, KajiM et al. Long-term benefits for the quality of life after video-assisted thoracoscopic lobectomy in patients with lung cancer. Surg Laparosc Endosc 1999;9:403-408. 21

\section{Walker WS, Codispoti M, Soon SY}

et al. Long-term outcomes following VATS lobectomy for non-small cell bronchogenic carcinoma. Eur J Cardiothorac Surg 2003;23:397-402. 23. 